\title{
The VAT Reform and Its Financial Impacts
}

\author{
Weimo Huang \\ School of Management \\ Xi'an University of Science and Technology \\ Xi'an 710054, China \\ E-mail: hwm740430@sina.com
}

\begin{abstract}
Since January $1^{\text {st }} 2009$, all regions and industries in China have implemented the VAT reform. Therefore, in this article, the author makes an analysis on the background of the VAT reform based on a review of the types of VAT and its reform practice. He also points out impact of the overall implementation of VAT on corporate finance.
\end{abstract}

Keywords: VAT reform, Production VAT, Consumption VAT, Financial impact

In November 11 2008, the State Council Standing Committee Conference decided that, VAT reform would be carried out in all regions and industries all around the country from January $1^{\text {st }} 2009$ in order to enlarge domestic demands, to reduce tax burden of corporate equipment investment, to promote technical progress, adjustment of industrial structure and to transform economic growth mode. This has been a single tax reform with the largest degree of tax abatement in the history of our country, which will bring significant influences to the corporate finance.

\section{Types of VAT and review of its reform practice}

VAT refers to a turnover tax levied on value added, which is realized in the process of producing and selling goods, or providing processing, repairs and replacement service. According to deduction of purchased permanent assets, VAT can be classified into three types, namely, production, consumption and income. In consumption VAT, in calculation of value added, it is allowed to completely deduct once withholdings on VAT contained in purchase of permanent assets. That is, the balance is regarded as a tax base, in which the monetary amount of consumed commodity and service is subtracted from a taxpayer's sales profit, and then the current purchased permanent asset amount is subtracted. In production VAT, in calculation of value added, it is not allowed to deduct withholdings on VAT contained in purchase of permanent assets. However, the balance is regarded as a tax base, in which the monetary amount of consumed commodity and service is subtracted from a taxpayer's sales profit. In income VAT, in calculation of value added, it is allowed to deduct respectively withholdings on VAT contained in purchase of permanent assets according to depreciation accrued currently. That is, the tax base of VAT is the balance in which the monetary amount of consumed commodity and service and permanent asset depreciation are subtracted from a taxpayer's sales profit. Currently, a majority of countries in the world adopt consumption VAT, while only several countries like China and Indonesia adopt production VAT.

\subsection{Implementation phase of production VAT}

In the tax system reform in 1994, China selected production VAT, which couldn't go without the productivity level and economic development environment of that time. On one hand, this was due to consideration of financial revenues; on the other hand, this was for inhibition of investment inflation. However, with further development of market economy, changes took place in the macro-economy in China, and deflation and insufficient market demand happened, so investment initiation was the top priority. Although we adopted positive financial policies, and monetary policies, and stimulate private investment by increasing national debt and governmental investment, yet the effect was not obvious. To deal with insufficient demand and deflation, merely the above two positive policies were not enough without cooperation of positive tax policies. Many issues revealed in the current production VAT indicated, reform on the current VAT is an urgent need of the economic development of China.

\subsection{Coexistence of production VAT and consumption VAT --- experimental period of VAT reform}

Due to double taxation in production VAT, and the fact that it goes against technical reform of enterprises, and, 
meanwhile, a lot of traditional enterprises were faced with issues of ageing equipment and heavy social burden in the process of market reform, Party's Sixteenth National Congress and the Third Plenary Session of its Sixteenth Central Committee made the decision of "transition of VAT from production to consumption, and including equipment investment in the scope of VAT deduction", which confirmed direction of China's VAT reform. Since July $1^{\text {st }} 2004$, the government implemented experimental work of VAT reform in 8 industries in Northeastern old industrial bases. During that year, rate of increase of GDP in the three provinces in Northeast was $2.8 \%$ higher than the average national level. Since July $1^{\text {st }} 2007$, China continued to implement experimental work of enlarging VAT deduction scope in 26 old industrial cities and over 12,000 enterprises in six central provinces after experimental work of VAT reform in Northeast. By the end of 2007, totally an amount of $¥ 3.45$ billon was refunded for these enterprises. Furthermore, in the 2007 government work report, working out of comprehensive implementation of VAT reform plans and measures of was definitely listed into work plan of the central government.

\subsection{Comprehensive implementation phase of consumption VAT}

Although experimental work of VAT reform was implemented in part of industries in part of regions, which could push forward growing up of these regions, this was only preference to part of taxpayers. If this situation continued, it would inevitably bring about unequal competition among different taxpayers from other areas, which would damage interests of a majority of taxpayers. In order to avoid negative effect of the reform, and to protect rights of equal taxing among taxpayers, The State Council Standing Committee Conference decided to implement VAT reform in all regions and industries around the country from January $1^{\text {st }} 2009$. The major content of the reform is as follows: to allow enterprises to deduct VAT contained in newly purchased equipment; to cancel exemption of VAT on imported equipment and drawback of VAT on purchase of home equipment by foreign-funded enterprises; to uniformly reduce VAT percentage charges of a small number of taxpayers to $3 \%$, and to recover VAT rate of minerals back to $17 \%$. It is calculated that, after the reform, revenue of VAT in the next year will be reduced by approximately $¥ 120$ billion.

\section{Analysis of background of VAT reform}

\subsection{Financial crisis provides opportunities for VAT reform}

Currently, financial crisis aroused by American subprime mortgage crisis has spread to Europe, Asia and Latin America. There appears a decelerating trend in the global economic growth, and the economic recessionary phenomenon even happens in some countries. Financial crisis is bringing about significantly unfavorable impacts on the real economy. Under such a circumstance, the timely VAT reform will play a quite important role in strengthening developmental potentials of an enterprise, improving corporate competition and risk resistance capacity, and overcoming unfavorable influences of international financial crisis on Chinese economy. It is calculated that, the finance of this reform exceeds $¥ 120$ billion, which has had the greatest degree of tax deduction of single tax system reform in the Chinese history. It is believed that, coming out of this policy will be an anxo-action to the lasting, stable and fast development of Chinese economy.

\subsection{Speedup of economy slides backward impels overall progress of VAT reform}

The current situation of slowdown of the economic speedup creates conditions for the overall unfolding of VAT reform. In the first half of 2008, the GDP of China increased $10.4 \%$ over the same period of the previous year, and the speed increasing ratio drops a percentage of 1.8. Due to several factors, SMEs are faced with difficulties of operation, and 67,000 SMEs around the whole country went bankrupt in the first half year. The VAT reform has also objectively had the effect of reducing burden of taxation by an enterprise, which can enlarge space for profits of the enterprise, elevating market competition of the enterprise, and helping more enterprises pull through, favorable for the realization of macro-control targets.

\subsection{Large surplus of the finance creates reforming conditions for VAT reform}

In the first seven months of 2008, it was accumulated that the national financial revenue reached $¥ 4088,171$ billion, which increased $30.5 \%$ over the same period of the previous year. According to experts, there would be no problems for the annual financial revenue to exceed $¥ 6000$ billion. In the first half of 2008 , the national budget revenue reached $¥ 3480,819$ billion, which increased $33.27 \%$ over the same period of the previous year, while the national budget expense reached $¥ 2288,202$ billion, which increased $27.69 \%$ over the same period of the previous year. And the surplus reached $¥ 1192,617$ billion. According to the Ministry of Finance, the VAT reform will cause the finance to reduce by $¥ 150$ billion to 200 billion, and the finance will suffer from a great pressure, while a relatively large surplus exists in the current finance, which creates conditions from another aspect for the VAT reform.

\subsection{VAT reform experimental units provide precious experiences for the overall reform}

The experimental units of VAT reform assume heavy responsibilities of supporting Northeastern development, rise of central China and exploring and perfecting VAT system, and the final target is to accumulate experiences for further promotion of VAT reform in China, and construction of standardized consumption VAT reform. Meanwhile, the target 
includes the effort to transform VAT reform from a preferential policy into a system arrangement, so as to reflect the neutral principle of taxation and to really realize fair taxation of taxpayers. Throughout all domestic and oversea VAT practices, only implementation of a consumption VAT with total depreciation and elimination of double taxation can really reflect fairness and neutrality of VAT, and protect rights of taxpayers. With over four years' experiments, we have already seen some issues of consumption VAT for improving capacity of an enterprise to make profit, for stimulating an enterprise to make full use of financial leverage effect and for improving international competition of a product, etc. Therefore, this reform has made regulations on fixed assets in the taxation incidence of VAT, only limited to machines, machinery, transportation vehicles, and other real estates related with production and operation, such as equipment, tools, implements, houses, and buildings, which can't be counted within the deduction scope of VAT.

\section{Impacts of VAT reform on corporate finance}

Impacts of VAT reform on corporate finance are various, and in the following, the author will only make specific analysis in its impacts on financial leverage effect and the related earnings per share and break-even analysis.

\subsection{Impacts of VAT reform on financial leverage effect}

Financial leverage effect is caused by existence of permanent expense. While one certain financial variable fluctuates with a relatively small amplitude, the other variable will fluctuate with a relatively large amplitude. Financial leverage effect mainly includes operating leverage and financial leverage.

\subsubsection{Impact of VAT reform on operating leverage effect}

Operating leverage refers to application of fixed cost in operating costs in operating activities by an enterprise. Fixed cost refers to the cost which remains unchanged under the influence of harvest fluctuation in a certain period and with a certain production capacity, including depreciation of fixed cost. Role of operating leverage can directly influence earnings before interest and tax of an enterprise. An enterprise can reduce fixed cost of the turnover of the enterprise through enlarging business sales, and increase operating profit of the enterprise, which is the purpose of operating leverage. The enterprise usually uses the degree of operating leverage (DOL) to express degree of operating leverage, which refers to proportion of its operating profit fluctuation ratio to the turnover fluctuation ratio.

$$
\mathrm{DOL}=\frac{\Delta E B I T / E B I T}{\Delta S / S}=\frac{S-V C}{S-V C-F}
$$

In the above formula, EBIT stands for earnings before interest and tax, $\triangle$ EBIT for fluctuation ratio of earnings before interest and tax, $S$ for sales income and $\triangle S$ for fluctuation ratio of sales income.

Under the circumstance in which other factors remain unchanged, the VAT reform might cause fluctuation of fixed cost, and further fluctuation of degree of operating leverage.

Supposing that merely handling way of withholdings on VAT of fixed assets is different before and after the VAT reform, and handling way of other financial indices remain unchanged. Let's suppose that the regular sales income of an enterprise is $\mathrm{y}$, sale price per unit is $\mathrm{p}$, variable cost is $\mathrm{VC}$, variable cost per unit is $b$, fixed cost in production VAT is $\mathrm{F}_{1}$, (including the depreciation cost $\mathrm{D}_{1}$ in fixed assets), fixed cost in consumption VAT is $\mathrm{F}_{2}$, (including the depreciation cost $\mathrm{D}_{2}$ in fixed assets), and suppose that other fixed cost remain unchanged except depreciation cost, then if $\mathrm{D}_{1}>\mathrm{D}_{2}$, and $\mathrm{F}_{1}>\mathrm{F}_{2}$. And the change of degree of operating leverage before and after VAT reform is as follows:

$$
\mathrm{DOL}_{1} \div \mathrm{DOL}_{2}=\frac{S-V C}{S-V C-F 1} \div \frac{S-V C}{S-V C-F 2}=\frac{S-V C-F 2}{S-V C-F 1}>1
$$

This proves that, after the VAT reform, the degree of operating leverage reduces, which means that beneficial space for an enterprise by means of operating leverage becomes small, but at the same time, the operating risk reduces.

\subsubsection{Impact of VAT reform on financial leverage effect}

Financial leverage refers to application of debt capital by an enterprise in financial activities. In the case when capital structure is fixed, debt capital is usually fixed, and can be deducted before the income tax. Therefore, when rate of return on investment is larger than debt capital, an enterprise can make use of financial leverage effect to bring extra gains to stockholders. Degree of application of financial leverage in corporate computation is generally expressed by degree of financial leverage (DFL), which refers to ratio between fluctuation ratio of earnings after tax and that of earnings before tax.

$$
\mathrm{DFL}=\frac{\Delta E A T / E A T}{\Delta E B I T / E B I T}=\frac{E B I T}{E B I T-I}
$$

EAT refers to earnings after tax, $\triangle \mathrm{EAT}$ refers to fluctuation ratio of earnings after tax, while I refers to annual amount of interests of the debt.

Under the circumstance when other factors remain unchanged, fluctuation of the fixed capital might be caused after the 
VAT reform, which, in turn, will cause fluctuation of degree of financial leverage.

$\mathrm{EBIT}_{1}=\mathrm{S}-\mathrm{VC}-\mathrm{F}_{1}$ in the production $\mathrm{VAT}$, and $\mathrm{EBIT}_{2}=\mathrm{S}-\mathrm{VC}-\mathrm{F}_{2}$ in the consumption VAT, from which we can get EBIT $_{2}-\mathrm{EBIT}_{1}=\mathrm{F}_{1}-\mathrm{F}_{2}=\mathrm{D}_{1}-\mathrm{D}_{2}>0$, then change of financial leverage degree before and after the VAT reform is as follows:

$$
\mathrm{DFL}_{1}-\mathrm{DFL}_{2}=\frac{E B I T 1}{E B I T 1-I}-\frac{E B I T 2}{E B I T 2-I}=\frac{D 1-D 2}{(E B I T 1-I)(E B I T 2-I)}>0
$$

This proves that, after the VAT reform, the degree of financial leverage reduces, which means that, space for an enterprise to make profit by means of financial leverage lessens, and, meanwhile, the financial risk it might assume also reduces accordingly.

\subsection{Impact of VAT reform on earnings per share}

Change of operating leverage might have impact on EBIT, which in turn, might impact earnings per share. Therefore, VAT reform will necessarily impact earnings per share.

Earnings per share $\mathrm{EPS}_{1}=\frac{(E B I T 1-I 1)(1-T)}{N 1}$ in the production VAT, and earnings per share $\mathrm{EPS}_{2}=\frac{(E B I T 2-I 2)(1-T)}{N 2}$ in the consumption VAT, among which $\mathrm{N}$ refers to number of common stocks, I refers to interest cost of debt capital, and $\mathrm{T}$ refers to income tax rate, supposed that dividend on preferred stock is not taken into consideration.

3.2.1 Supposed that an enterprise needn't raise fund exteriorly in newly purchased equipment, namely, $I_{1}=I_{2}, N_{1}=N_{2}$, then change of earnings per share before and after the VAT reform is as follows:

$$
\begin{aligned}
\mathrm{EPS}_{2}-\mathrm{EPS}_{1} & =\frac{(E B I T 2-I 2)(1-T)}{N 2}-\frac{(E B I T 1-I 1)(1-T)}{N 1} \\
& =\frac{(E B I T 2-E B I T 1)(1-T)}{N}>0
\end{aligned}
$$

3.2.2 Supposed that an enterprise need raise fund exteriorly in newly purchased equipment, the fund needed has two forms of liabilities and interest, and in the case when capital structure remains unchanged, namely, $I_{1}>I_{2}, N_{1}>N_{2}$, then change of earnings per share before and after the VAT reform is as follows:

$$
\begin{aligned}
\mathrm{EPS}_{2} \div & \mathrm{EPS}_{1}=\frac{(E B I T 2-I 2)(1-T)}{N 2} \div \frac{(E B I T 1-I 1)(1-T)}{N 1} \\
= & \frac{(E B I T 2-I 2) N 1}{(E B I T 1-I 1) N 2}>1
\end{aligned}
$$

This proves that, whether an enterprise needs to raise fund exteriorly in newly purchased equipment after the VAT reform, earnings per share of its stockholders will increase, which is quite favorable for an enterprise to upgrade its developmental potential and industrial competition.

\subsection{Impact of VAT reform on break-even analysis}

After the VAT reform, it is allowed to deduct withholdings on VAT, which will reduce fixed depreciation expense per unit and which will have effect on the breakeven point, margin of safety, and margin rate of safety.

\subsubsection{Impact of VAT reform on breakeven point}

The so-called breakeven point refers to the sale condition in which scale of an enterprise's operation (sales volume or sales amount) exactly enables the enterprise to be break-even. This index provides ultimate portfolio information to prevent loss of the enterprise, and paves the way for judging the future operation safety degree and realizing profit of the enterprise.

Sales amount of the breakeven point in the production VAT is $\mathrm{y}_{1}=\frac{F 1}{p-b}$, and sales amount of the breakeven point in 
the consumption VAT is $\mathrm{y}_{2}=\frac{F 2}{p-b}$, then change of sales amount of the breakeven point before and after the VAT reform is $\mathrm{y}_{1}-\mathrm{y}_{2}=\frac{D 1-D 2}{p-b}>0$, which proves that, after the VAT reform the breakeven point reduces. In this way, space for an enterprise to make profit is enlarged, which is also beneficial for improving market competition of an enterprise. 3.3.2 Impact of VAT reform on margin rate of safety

Margin of safety refers to balance between orderly sales volume or current sales volume (including sales volume and sales amount) and sales volume of the breakeven point. Margin rate of safety refers to ratio of margin of safety to the current sales or orderly sales volume. Then the margin of safety in the production VAT is $\mathrm{MS}_{1}=\mathrm{y}-\frac{F 1}{p-b}$, and the margin rate of safety is $\mathrm{MR}_{1}=\frac{M S 1}{y}$; the margin of safety in the consumption $\mathrm{VAT}$ is $\mathrm{MS}_{2}=\mathrm{y}-\frac{F 2}{p-b}$, and the margin rate of safety is $\mathrm{MR}_{2}=\frac{M S 2}{y}$; change of the margin of safety before and after the VAT reform is $\mathrm{MS}_{2}-\mathrm{MS}_{1}=$ $\frac{D 1-D 2}{p-b}>0$, and change of the margin rate of safety is $\mathrm{MR}_{2}-\mathrm{MR}_{1}=\frac{M S 2-M S 1}{y}=\frac{D 1-D 2}{y(p-b)}>0$. Both margin of safety and margin rate of safety are above zero, which proves that, after the VAT reform, operation and safety condition of an enterprise is better.

\section{References}

Cao, Haimin \& Zhu, Chuanhua. (2004). Management Accounting. Beijing: Tsinghua University Press, 60-76.

Wang, Honghai \& Song, Lijuan. (2007). Calculation and Analysis of VAT Reform Operating Leverage Effect. China Management Informationization, (3), 35-37.

Yuan, Shan. (2008). Promotion of Economic Increasing downslide in VAT Reform. China Business News, September 2.

Zhang, Mengyu. (2008). The Research of VAT Reform of Our Country. Huabei Finance, 7.

Zhang, Yang. (2008). Analysis of Impact of VAT in China. Reform and Strategy, 6. 